\title{
Effect of Dexamethasone on Pulmonary Surfactant Metabolism in Hyperoxia-Treated Rat Lungs
}

\author{
TAMAKI OHASHI, SATOSHI TAKADA, TOSHIYUKI MOTOIKE, SYUICHI TSUNEISHI, \\ MASAFUMI MATSUO, KIMIHIKO SANO, AND HAJIME NAKAMURA \\ Department of Pediatrics, Kobe University School of Medicine, Kobe, Japan
}

\begin{abstract}
We have examined the effect of dexamethasone on the metabolism of pulmonary surfactant in normal and hyperoxia-treated rats. The relative abundance of the surfactant-specific apoprotein A (SP-A) mRNA in lung tissues and the contents of disaturated phosphatidylcholine (DSPC) and SP-A were measured in bronchoalveolar lavage fluids and in lung tissues in 4-wk-old rats exposed to room air or $>90 \%$ oxygen for $7 \mathrm{~d}$ with or without simultaneous treatment with dexamethasone $(0.5 \mathrm{mg} / \mathrm{kg}$ body wt for $7 \mathrm{~d}$ ). The relative abundance of the SP-A mRNA was marginally increased by hyperoxia (1.3-fold over controls). Dexamethasone increased the relative abundance of the SP-A mRNA to a level comparable to that with hyperoxia treatment (1.5-fold over controls). In lavage fluids, the contents of DSPC and SP-A were increased by 4- and 6-fold over controls by hyperoxia, respectively, but they were increased only by 2 -fold by dexamethasone. In lung tissues, the contents of DSPC and SP-A were increased by 3- and 2-fold over controls by hyperoxia, respectively. These values in lung tissues in the air-exposed rats were not significantly increased by dexamethasone. In hyperoxia-treated rats, dexamethasone did not significantly affect the relative abundance of the SP-A mRNA level and the contents of DSPC and SP-A in lavage fluids and lung tissues. These results indicate that mechanisms other than increased synthesis of SP-A are involved in hyperoxiainduced SP-A accumulation and that dexamethasone does not affect the abnormal accumulation of pulmonary surfactant induced by hyperoxia. (Pediatr Res 29: 173-177, 1991)
\end{abstract}

\section{Abbreviations}

SP-A, surfactant-specific apoprotein A DSPC, disaturated phosphatidylcholine BPD, bronchopulmonary dysplasia SSC, sodium chloride, sodium citrate

Therapeutic oxygen given to premature infants having respiratory distress syndrome has adverse effects on lungs and may give rise to a chronic lung disorder known as BPD (1). Multiple factors are involved in the pathogenesis of BPD, i.e. deficiency of pulmonary surfactant, mechanical stress, immaturity of lung antioxidant enzymes, and imbalance between protease and an-

Received February 27, 1990; accepted September 18, 1990.

Correspondence: Kimihiko Sano, M.D., Ph.D., Department of Pediatrics, Kobe University School of Medicine, Kusunoki-cho 7-5-2, Chuo-ku, Kobe, 650, Japan.

Supported by a Grant-in-Aid for Scientific Research from the Ministry of Education, Science, and Culture, Japan (1989) and by a grant from the Naito Foundation (1989). tiprotease in the airway (2). Accumulating evidence has suggested that high oxygen concentration in the airway plays a major role in the development of BPD (3-6). Prolonged exposure of animals to hyperoxia has been associated with progressive injury to cell components of the blood gas barrier, leading to increased alveolar and pulmonary vascular permeability, pulmonary edema, atelectasis, and eventually death from hypoxemia or respiratory failure (7). It has been reported that hyperoxia increased the airway content of SP-A, which is the most abundant nonserum protein in pulmonary surfactant with a mol wt between 26000 and 36 000 , and the SP-A mRNA in adult rats $(8,9)$. Dexamethasone has been successfully used for the treatment of BPD (10-12); it has been also shown to increase the SP-A mRNA level and the amount of SP-A both in vivo and in vitro $(13,14)$. We conducted this study to clarify the mechanisms of hyperoxia-induced SP-A accumulation in the airway by comparing the effect of dexamethasone on the SP-A metabolism with that of hyperoxia. The results were further analyzed to determine the possible preventive effect of dexamethasone on the acute oxygen toxicity represented by the abnormal accumulation of pulmonary surfactant.

\section{MATERIALS AND METHODS}

Materials. Horseradish peroxidase was purchased from Sigma Chemical Co. (St. Louis, MO). Sphingomyelinase, choline oxidase, and phospholipase D were kindly provided by Toyo Jozo (Shizuoka, Japan). Rabbit anti-rat SP-A polyclonal antibody and affinity-purified SP-A were generous gifts of Drs. Y. Kuroki, D. R. Voelker, and R. J. Mason (Department of Medicine, National Jewish Center for Immunology and Respiratory Medicine, Denver, CO). Rat SP-A cDNA was cloned and sequenced as previously described (15). The plasmid containing rat $\alpha$-tubulin cDNA (pIL $\alpha \mathrm{TI}$ ) was kindly provided by Dr. S. Farmer (Boston University, Boston, MA). Sodium 2-hydroxy-3,5-dichlorobenzensulfonate (HDCBS) was obtained from Aldrich Chemical Co., Inc. (Milwaukee, WI).

Animals and experimental design. Four-wk-old male Wistar rats were divided into the air group and the hyperoxia group. The former were maintained in room air. The latter were placed in a Plexiglas chamber $(40 \mathrm{~cm} \times 42 \mathrm{~cm} \times 50 \mathrm{~cm})$ under continuous oxygen flow at $5 \mathrm{~L} / \mathrm{min}$. The concentration of oxygen was greater than $90 \%$ and that of carbon dioxide was less than $0.5 \%$. Some rats were injected i.p. with a serial dose of dexamethasone $(0.5 \mathrm{mg} / \mathrm{kg} / \mathrm{d})$ every day during the study. An equal volume of saline was given to others in a similar fashion. The study design was approved by the animal care committee at Kobe University School of Medicine.

Lavage collection and preparation of lung tissues. After a 7-d exposure period, rats received a lethal i.p. injection of pentobarbital $(50 \mathrm{mg} / \mathrm{kg})$. Leaving the thorax undisturbed, the tracheas were cannulated and connected to the syringe. The lungs were slowly inflated at $30 \mathrm{~cm} \mathrm{H}_{2} \mathrm{O}$ pressure with cold $\mathrm{PBS}$, and this 
volume was recorded as $\mathrm{V}_{30}$. This pressure was maintained for 5 min before deflation. After a 5-min equilibration period, the lungs were lavaged 10 times with cold PBS with a volume equal to $80 \%$ of $V_{30}$. Fresh buffer was used for each lavage. Total recovered lavage fluids from each rat had to be at least $85 \%$ of the volume instilled to verify the analysis. The lungs were removed from the chest cavity immediately after lavage and separated into the right and left lobe. The former was placed in PBS containing $1 \%$ (vol/vol) Triton X-100 (1\% Triton X-100/PBS) for determination of DNA, DSPC, and SP-A. The latter was placed in $4 \mathrm{M}$ guanidinium isothiocyanate containing $0.1 \mathrm{M} \beta$ mercaptoethanol and $25 \mathrm{mM}$ sodium acetate for preparation of RNA. Both were homogenized with a Polytron and stored at $-80^{\circ} \mathrm{C}$ until the assays were performed.

Determination of DSPC. Lipids were extracted in chloroform/ methanol (1/2) according to Bligh and Dyer (16). Samples of chloroform/methanol extract were taken to dryness under a nitrogen stream and reacted with osmium tetroxide. Then each sample was applied to an alumina column and DSPC was eluted with chloroform/methanol/ $\mathrm{H}_{2} \mathrm{O} / \mathrm{NH}_{4} \mathrm{Cl}(70 / 30 / 1 / 1)$ as described by Mason et al. (17). DSPC was determined by the enzymatic method essentially as described by Muneshige et al. (18). In brief, choline was released from DSPC in reaction with phospholipase D and subsequently hydrogen peroxide was generated in reaction with choline oxidase. Hydrogen peroxide generated was quantified spectrophotometrically at $510 \mathrm{~nm}$ after the addition of horseradish peroxidase, aminoantipyrine, and HDCBS.

Measurement of $S P-A$. The amount of SP-A was measured by a double sandwich ELISA using a rabbit anti-rat SP-A polyclonal antibody. The assay was capable of accurately measuring SP-A in concentrations of $1-20 \mathrm{ng} / \mathrm{mL}$. Anti-SP-A IgG fraction (100 $\mu \mathrm{g} / \mathrm{mL}$ in $0.1 \mathrm{M} \mathrm{NaHCO}_{3}$ ) was incubated overnight at room temperature in wells of untreated 96-well microtiterplates (Dynatech Corp., Chantilly, VA). The wells were then incubated in PBS containing $1 \%$ (vol/vol) Triton X-100 and 3\% (wt/vol) BSA (3\% BSA/1\% Triton X-100/PBS). After two washes with $1 \%$ Triton $\mathrm{X}-100 / \mathrm{PBS}, 100 \mu \mathrm{L}$ of affinity-purified rat SP-A standard (0-20 ng in $5 \mathrm{mM}$ Tris/ $\mathrm{HCl}, \mathrm{pH} 7.0)$ or various dilutions of samples were added to each well and allowed to incubate at $37^{\circ} \mathrm{C}$ for $90 \mathrm{~min}$. After the wells were washed three times with $3 \%$ BSA/1\% Triton X-100/PBS, $100 \mu \mathrm{L}$ of biotinylated anti-SP-A IgG fraction were added to each well and allowed to incubate at $37^{\circ} \mathrm{C}$ for $90 \mathrm{~min}$. Anti-SP-A IgG was biotinylated using a biotinylation kit from Amersham (Arlington Heights, IL). After four washes with $1 \%$ Triton X-100/PBS, $100 \mu \mathrm{L}$ of diluted horseradish peroxidase-conjugated streptavidin (Amersham) were added to each well and allowed to incubate at $37^{\circ} \mathrm{C}$ for $30 \mathrm{~min}$. After three washes with $1 \%$ Triton X-100/PBS, $100 \mu \mathrm{L}$ of substrate solution $\left\{1 \mathrm{mM} 2,2^{\prime}\right.$-azino-di[3-ethyl-benzthiazoline sulfonate (6)] with $0.002 \%$ (vol/vol) hydrogen peroxide in citrate buffer\} were added to each well. The reaction was stopped by the addition of $50 \mu \mathrm{L}$ of $1.5 \mathrm{mM}$ sodium azide in $0.1 \mathrm{M}$ citric acid. The absorbance at $410 \mathrm{~nm}$ was recorded with a Microplate Autoreader (Bio Rad Laboratories, Richmond, CA).

Determination of $D N A$. DNA samples were prepared from 0.2 $\mathrm{mL}$ of the lung homogenate by precipitation with $10 \%$ perchloric acid followed by extraction with methanol and ether. The amount of DNA was then determined fluorometrically using diaminobenzoic acid as described by Setaro and Morley (19).

$R N A$ analysis. Total RNA was extracted from lung tissues with $4 \mathrm{M}$ guanidinium isothiocyanate containing $0.1 \mathrm{M} \beta$-mercaptoethanol and $25 \mathrm{mM}$ sodium acetate. RNA was purified by centrifuging the lysate through a cushion of $5.7 \mathrm{M}$ cesium chloride at $80000 \times g$ for $16 \mathrm{~h}$ at $22^{\circ} \mathrm{C}$. The amount of RNA was quantitated by measurement of OD at $260 \mathrm{~nm}$. For the Northern blot analysis, total RNA $(20 \mu \mathrm{g})$ was size-fractionated by electrophoresis on a $1 \%$ agarose gel containing $3 \%$ formaldehyde and $0.5 \mu \mathrm{g} / \mathrm{mL}$ of ethidium bromide, and transferred to a nylon membrane sheet (Gene Screen from NEN Research
Products, Boston, MA) by capillary action in $10 \times \operatorname{SSC}(1 \times$ SSC; $0.15 \mathrm{M} \mathrm{NaCl}$ and $0.015 \mathrm{M}$ sodium citrate). For dot blot analysis, 1 to $10 \mu \mathrm{g}$ of total RNA in $10 \times \mathrm{SSC}$ were charged onto a nylon membrane sheet under vacuum.

After baking at $80^{\circ} \mathrm{C}$ for $3 \mathrm{~h}$, the membrane was prehybridized at $42^{\circ} \mathrm{C}$ overnight in $5 \times \mathrm{SSC}, 0.5 \% \mathrm{SDS}, 3 \times$ Denhardt's solution $(1 \times$ Denhardt's solution; $0.02 \%$ Ficoll, $0.02 \%$ polyvinylpyrrolidone, and $0.02 \%$ BSA), $0.2 \mathrm{mg} / \mathrm{mL}$ salmon sperm DNA, and $45 \%$ formamide and then hybridized in the same solution that additionally contained $1.0 \times 10^{6} \mathrm{cpm} / \mathrm{mL}$ of a ${ }^{32} \mathrm{P}$-labeled cDNA probe for rat SP-A. The probe was labeled using a random primer labeling kit (Amersham) with $\left[\alpha-{ }^{32} \mathrm{P}\right]$ deoxycytidine triphosphate. After a 24-h hybridization period, the membrane was washed twice in $2 \times \mathrm{SSC}$ at room temperature for $5 \mathrm{~min}$, twice in $2 \times$ SSC containing $0.1 \% \mathrm{SDS}$ at $65^{\circ} \mathrm{C}$ for $30 \mathrm{~min}$, and finally twice in $0.1 \times \mathrm{SSC}$ at room temperature for $30 \mathrm{~min}$. Then the membrane was exposed to a Kodak X-Omat AR film with an intensifying screen at $-70^{\circ} \mathrm{C}$ for $24 \mathrm{~h}$. To quantify the relative amounts of the SP-A mRNA, the film was scanned at $550 \mathrm{~nm}$ using a Dual-wavelength TLC Scanner (CS-930, Shimadzu, Kyoto, Japan) and the area corresponding to each dot was computed. The area of each dot in a single sample was well correlated with the amount of total RNA charged. The average of the areas corresponding to $4 \mu \mathrm{g}$ of total RNA recovered from control rats was expressed as 1 arbitrary unit and then the value of each sample was calculated and expressed as arbitrary units per $4 \mu \mathrm{g}$ of total RNA. To assure the even loading of total RNA, the same membrane sheet was rehybridized with rat $\alpha$-tubulin cDNA probe.

Purification of pulmonary surfactant. Pulmonary surfactant was isolated from the lavage fluids of the air group and the hyperoxia group according to the method described by Hawgood et al. (20). The pooled lung lavage fluids were spun at $150 \times g$ for $15 \mathrm{~min}$ to remove contaminating cells and cell debris. The supernatant was then spun at $20000 \times g$ for $15 \mathrm{~h}$ at $4^{\circ} \mathrm{C}$ and the resulting pellet was dispersed in $5 \mathrm{mM}$ Tris/ $\mathrm{HCl}$ at $\mathrm{pH} 7.0$ containing $100 \mathrm{mM} \mathrm{NaCl}$ and $1.64 \mathrm{M}$ sodium bromide. After equilibration for $1 \mathrm{~h}$, this suspension was spun at $100000 \times g$ for $4 \mathrm{~h}$ at $4^{\circ} \mathrm{C}$. The pellicle was resuspended in the same buffer without sodium bromide and then spun at $100000 \times g$ for $1 \mathrm{~h}$ at $4^{\circ} \mathrm{C}$. The pellet was resuspended in distilled water and subjected to electrophoresis.

Electrophoresis and Western blot analysis. Pulmonary surfactant-associated proteins were separated by SDS-PAGE as described by Laemmli (21) and transferred electrophoretically to a nitrocellulose sheet (Schleicher and Schuell, Inc., Keene, NH). The sheet was treated with PBS containing 3\% (wt/vol) BSA (3\% BSA/PBS) to block nonspecific binding, and subsequently reacted with biotinylated anti-SP-A IgG followed by horseradish peroxidase-conjugated streptavidin (Amersham). Diaminobenzidine was used as a substrate for the peroxidase reaction.

Statistical analysis. Data are expressed as mean \pm SEM. Statistical analysis was performed with analysis of variance for multiple comparisons with the Statview statistical program.

\section{RESULTS}

Body weights, lung DNA contents, and lavage volume. The number of rats studied and their body weights, lung DNA contents, and $V_{30}$ are shown in Table 1 . One out of five rats treated with hyperoxia plus dexamethasone died during the study. Body weight gain of the dexamethasone-treated group, the hyperoxia group, and the hyperoxia plus dexamethasone-treated group was significantly less than that of the air group. Lung DNA contents were not significantly different among the four groups. $\mathrm{V}_{30}$ of the hyperoxia group and the hyperoxia plus dexamethasone-treated group was significantly less than that of the air group.

The relative amount of the SP-A $m R N A$. Rat SP-A cDNA probe hybridized with two species of $\mathrm{mRNA}$, the sizes of which 
Table 1. Body weight, lung DNA content, and lavage volume

\begin{tabular}{|c|c|c|c|c|c|c|c|c|c|c|}
\hline \multirow[b]{3}{*}{ Room air $(n=5)$} & \multicolumn{4}{|c|}{ Body wt (g) } & & & & & & \\
\hline & $0 \mathrm{~d}$ & & $7 \mathrm{~d}$ & & \multicolumn{3}{|c|}{ DNA $(\mu \mathrm{g})$} & \multicolumn{3}{|c|}{$\mathrm{V}_{30}(\mathrm{~mL})$} \\
\hline & $77 \pm 4$ & $117 \pm 47$ & \multirow{2}{*}{$*$} & & $48.8 \pm 3.27$ & \multirow{2}{*}{ NS } & & $6.8 \pm 0.4-$ & \multirow{2}{*}{ NS } & \\
\hline Room air + dexamethasone $(n=5)$ & $77 \pm 4$ & $92 \pm 2\rfloor$ & & * & $35.2 \pm 1.6]$ & & NS & $5.8 \pm 0.3]$ & & * \\
\hline Hyperoxia $(n=5)$ & $75 \pm 5$ & $87 \pm 7$ & NS & & $36.0 \pm 2.8$ & NS & & $3.7 \pm 0.27$ & NS & \\
\hline
\end{tabular}

${ }^{*} p<0.05$ when compared to the air group.
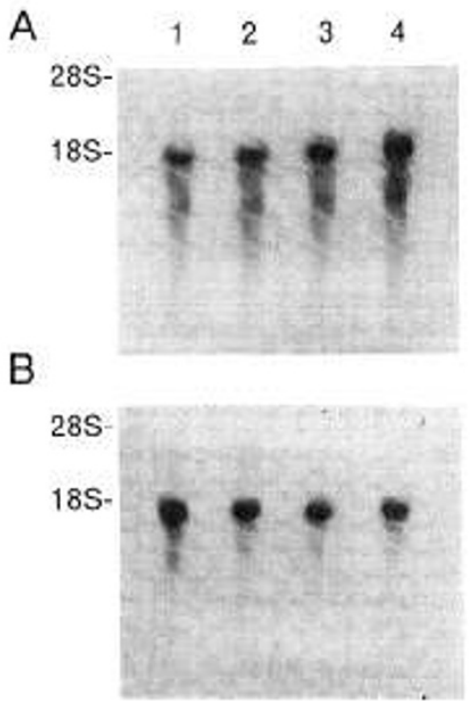

Fig. 1. The relative abundance of the SP-A and $\alpha$-tubulin mRNA in lungs of air- or hyperoxia-exposed rats with or without treatment with dexamethasone. Total RNA was extracted from rat lungs in each group. Total RNA ( $20 \mu \mathrm{g})$ was electrophoresed, transferred to a nylon membrane sheet, and hybridized with the radiolabeled SP-A cDNA probe. The same membrane was hybridized with the $\alpha$-tubulin cDNA probe after stripping off the SP-A cDNA. $A$, the SP-A mRNA; $B$, the $\alpha$-tubulin mRNA. Lane 1 , the air group; lane 2 , the hyperoxia group; lane 3 , the dexamethasone group; lane 4 , the hyperoxia plus dexamethasone group.

were 1.6 and $0.9 \mathrm{~kb}$, as described previously (22) (Fig. 1). The nucleotide sequences of the coding region of these two corresponding cDNA are the same, and the difference in the size between these two mRNA is attributed to the different lengths of the $3^{\prime}$-noncoding region (22). Which $\mathrm{mRNA}$ species is mainly translated into SP-A is not known. The relative abundance of the SP-A mRNA in the hyperoxia group, dexamethasone group, or hyperoxia plus dexamethasone group was higher than that in the air group (Fig. 1). The relative abundance of the two species of mRNA in lung tissues was not different among four groups. The relative abundance of the $\alpha$-tubulin mRNA was not different among four groups. The relative abundance of the SP-A mRNA in each group was determined by dot blot analysis and is shown in Table 2. Hyperoxia increased the relative abundance of the SP-A mRNA by 1.3-fold over the control group. Dexamethasone increased the relative abundance of the SP-A mRNA by 1.5 -fold over the control group. The relative abundance of the SP-A mRNA in the hyperoxia plus dexamethasone-treated group showed a 2.2-fold increase over that in the air group. The relative abundance of the $\alpha$-tubulin mRNA was not significantly different in four groups.

Contents of $S P$ - $A$ and DSPC in lavage fluids and lung tissues. Table 3 shows the contents of SP-A and DSPC in lavage fluids. Hyperoxia increased the contents of SP-A and DSPC in lavage fluids by approximately 6- and 4-fold over the controls, respectively. Dexamethasone increased the contents of both SP-A and
Table 2. $S P-A m R N A$ levels in lung tissues

\begin{tabular}{|c|c|c|c|}
\hline \multirow[b]{2}{*}{ Room air $(n=10)$} & \multicolumn{3}{|c|}{ Arbitrary unit* } \\
\hline & $1.0 \pm 0.17$ & & \\
\hline Room air + dexamethasone $(n=5)$ & $1.5 \pm 0.1]$ & & $\dagger$ \\
\hline Hyperoxia $(n=10)$ & $1.3 \pm 0.17$ & J & \\
\hline Hyperoxia + dexamethasone $(n=4)$ & $2.2 \pm 0.5]$ & & \\
\hline
\end{tabular}

DSPC by approximately 2-fold over the controls. Dexamethasone did not significantly affect these values in the hyperoxia group. The contents of SP-A and DSPC in lung tissues in each group are shown in Table 4. Hyperoxia increased the contents of SP-A and DSPC in lung tissues by about 3- and 2-fold over the controls, respectively. In both the air and the hyperoxia groups, the effects of dexamethasone on the contents of SP-A and DSPC in lung tissues were not significant.

\section{DISCUSSION}

We confirmed the results reported by Nogee and Wispe (8) that hyperoxia increases the contents of DSPC and SP-A, major components of the pulmonary surfactant, both in lavage fluids and in lung tissues in rats. SP-A recovered from hyperoxiatreated rats was thought to be biologically similar to native SP$A$ in that they show the same mobility in SDS-PAGE (data not shown). The increase in the airway contents of DSPC and SP-A by hyperoxia could be attributed to either the increased synthesis and/or secretion or the decreased catabolism of the pulmonary surfactant. We have shown that hyperoxia increases the relative abundance of the SP-A mRNA by 1.3-fold over controls, whereas hyperoxia increased the SP-A content in lavage fluids and in lung tissues over the controls by 6 - and 3-fold, respectively. Nogee et al. (9) reported that exposure to $85 \%$ oxygen increases the airway content of SP-A by 20 -fold and SP-A mRNA by $10-$ fold in adult rats. The exact reason for the discrepancy between their results and ours is not known. However, one of the reasons for this may be the different age and strain of the rats used in our experiments. In our experience, significant numbers of adult rats ( 8 to $16 \mathrm{wk}$ old) died during hyperoxia treatment, which is the reason we used young rats in our study. Yam et al. (23) also reported that all 4-wk-old or younger rats survived the 3-d oxygen exposure, but only $25 \%$ of rats older than 7 wk old were alive (23). Therefore, adult rat lungs may be more susceptible to hyperoxia than are young rat lungs, resulting in large increases in the SP-A content and the relative abundance of the SP-A mRNA. The rats younger than 4 wk old were not suitable for our study because it was difficult to recover lavage fluids correctly. Floros et al. (14) have reported that consistent results were not obtained using 28-d-old rats in similar experiments, probably because of the delicate hormone balance in this specific period. However, we could obtain fairly consistent results in terms of 
Table 3. Contents of SP-A and DSPC in lavage fluids

$\left.\left.\begin{array}{lcc}\hline & \text { SP-A }(\mu \mathrm{g} / \mathrm{g} \text { body wt) } & \text { DSPC (nmol/g body wt) } \\ \hline \text { Room air }(n=11) & 0.54 \pm 0.08 \\ \text { Room air + dexamethasone }(n=5) & 1.14 \pm 0.29\end{array}\right] * \begin{array}{c}2.90 \pm 0.28 \\ 6.24 \pm 0.78\end{array}\right]+\begin{gathered}* \\ \text { Hyperoxia }(n=11) \\ \text { Hyperoxia + dexamethasone }(n=4)\end{gathered}$

$* p<0.05$ when compared to the air group.

$\dagger p<0.01$ when compared to the air group.

Table 4. Contents of SP-A and DSPC in lung tissues

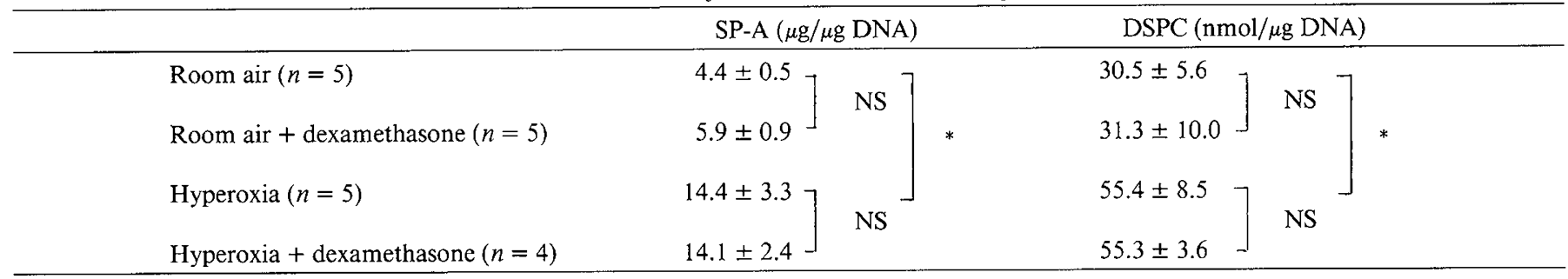

$* p<0.05$ when compared to the air group.

the content of SP-A and the relative abundance of the SP-A mRNA (Tables 2-4). The exact reason for the discrepancy between their results and ours is not known. However, one possible reason could be the use of different protocols. Floros et al. examined the effects of oxygen treatment after a 24-h exposure (14), and we examined the effects of daily treatments for a total of $7 \mathrm{~d}$.

Pulmonary surfactant is synthesized and secreted by alveolar type II cells (24). The increase in the SP-A mRNA level by hyperoxia might be attributed to the increase in the number of alveolar type II cells, the increase in the transcriptional rate of the SP-A gene, or a change in message stability. Young et al. (25) reported that rats exposed to $85 \%$ oxygen for $7 \mathrm{~d}$ had lungs that contained twice the number of alveolar type II cells compared with control rats (25). Because we have not measured the number of alveolar type II cells, the contribution of the increase in the number of alveolar type II cells to the increased airway content of pulmomary surfactant by hyperoxia is not known. Dexamethasone increases the relative abundance of the SP-A mRNA by 1.5 -fold over the controls (Table 2) and increases the airway content of SP-A by 2 -fold (Table 3 ). Dexamethasone does not significantly affect the content of SP-A in lung tissues (Table 4). From the comparison of these values between the hyperoxia group and the dexamethasone group, the increase in the content of SP-A both in lung tissues and lavage fluids in hyperoxiatreated rats cannot be fully explained by the increase in the relative abundance of the SP-A mRNA. Other mechanisms might be employed in the hyperoxia-induced large increase in the airway content of SP-A, such as the decreased catabolism of SP-A.

Accumulated evidence has shown that secreted pulmonary surfactant is taken up from the alveolar lumen by alveolar type II cells and reutilized for the synthesis of pulmonary surfactant (26). Furthermore, a significant portion of the pulmonary surfactant is taken up and metabolized by alveolar macrophages (26). We have previously reported that the function of alveolar macrophages recovered from rat lungs exposed to hyperoxia is significantly decreased when assessed by superoxide anion production (27). Therefore, impaired function of alveolar macrophages resulting in decreased uptake of the pulmonary surfactant might be one of the causes of the increase in the contents of DSPC and SP-A in lavage fluids of hyperoxia-treated rats. Because the primary site of acute oxygen toxicity has been considered to be plasma membranes (28), there is a possibility that hyperoxia impaired the uptake mechanism of SP-A by alveolar type II cells due to the damage of the plasma membrane. To examine these possibilities, however, the study of the clearance rate of surfactant in each cell type is required.

The effect of hyperoxia on the synthesis of DSPC is unknown. However, because the content of DSPC is also increased in lung tissues and lavage fluids to a similar extent as that of SP-A in hyperoxia-treated rats as shown in Tables 3 and 4, the same mechanism might be used to cause these changes in the amount of DSPC.

Dexamethasone has been successfully used for the treatment for BPD (10-12). Therefore, we examined the effect of dexamethasone on the pulmonary surfactant metabolism in hyperoxia-treated rats. Dexamethasone treatment does not significantly affect the contents of DSPC and SP-A in either lavage fluids or lung tissues in hyperoxia-treated rats as shown in Tables 3 and 4. Therefore, dexamethasone does not have preventive effect on the acute oxygen toxicity to lungs represented by the accumulation of pulmonary surfactant.

Acknowledgment. The authors thank Lavonne Schrieber for careful reading of the manuscript.

\section{REFERENCES}

1. Northway Jr WH, Rosen RC, Porter DY 1967 Pulmonary disease following respiratory therapy of hyaline membrane disease: bronchopulmonary dysplasia. N Engl J Med 276:357-368

2. Goetzman BW 1986 Understanding bronchopulmonary dysplasia. Am J Dis Child 140:332-334

3. Bonikos DS, Bensch KG, Northway Jr WH 1976 Oxygen toxicity in the newborn. The effect of chronic continuous 100 percent oxygen exposure on the lungs of newborn mice. Am J Pathol 85:623-650

4. Edwards DK, Dyer WH, Northway Jr WH 1977 Twelve years' experience with bronchopulmonary dysplasia. Pediatrics 59:839-846

5. Pappas CTE, Obara H, Bensch KG, Northway WH 1983 Effect of prolonged exposure to $80 \%$ oxygen on the lung of the newborn mouse. Lab Invest 48:735-748

6. de Lemos RA, Coalson JJ, Gerstmann DR, Kuehl TJ, Null DM 1987 Oxygen toxicity in the premature baboon with hyaline membrane disease. Am Rev Respir Dis 136:677-682

7. Clark JM, Lambertsen CJ 1971 Pulmonary oxygen toxicity: a review. Pharmacol Rev 23.37-133

8. Nogee LM, Wispe JR 1988 Effects of pulmonary oxygen injury on airway content of surfactant-associated protein A. Pediatr Res 24:568-573

9. Nogee LM, Wispe JR, Clark JC, Whitsett JA 1989 Increased synthesis and mRNA of surfactant protein A in oxygen-treated rats. Am J Respir Cell Mol Biol 1:119-125

10. Mammel MC, Green PG, Johnson DE, Thompson TR 1983 Controlled trial of dexamethasone therapy in infants with bronchopulmonary dysplasia. Lancet 1:1356-1358 
11. Avery GB, Fletcher AB, Kaplan M, Brudno DS 1985 Controlled trial of dexamethasone in respirator dependent infants with bronchopulmonary dysplasia. Pediatrics 75:106-111

12.Mammel MC, Fiterman C, Coleman M, Boros SJ 1987 Short-term dexamethasone therapy for bronchopulmonary dysplasia: acute effects and 1-year follow-up. Dev Pharmacol Ther 10:1-11

13. Mendelson CR, Chen C, Boggaram V, Zacharias C, Snyder JM 1986 Regulation of the synthesis of the major surfactant apoprotein in fetal rabbit lung tissue. J Biol Chem 261:9938-9943

14. Floros J, Phelps DS, Harding HP, Church S, Ware J 1989 Postnatal stimulation of rat surfactant protein $\mathrm{A}$ synthesis by dexamethasone. Am J Physiol 257:L137-L143

15. Sano K, Fisher J, Mason RJ, Kuroki Y, Schilling J, Benson B, Voelker D 1987 Isolation and sequence of a cDNA clone for the rat pulmonary surfactantassociated protein (PSP-A). Biochem Biophys Res Commun 144:367-374

16. Bligh EG, Dyer WJ 1959 A rapid method of total lipid extraction and purification. Can J Biochem 37:911-917

17. Mason J, Nellenbogen J, Clements JA 1976 Isolation of disaturated phosphatidylcholine with osmium tetroxide. J Lipid Res 17:281-284

18. Muneshige A, Okazaki T, Quirk JG, MacDonald PC, Nozaki M, Johnston JM 1983 A rapid and specific enzymatic method for the quantification of phosphatidylcholine, disaturated phosphatidylcholine, and phosphatidylglycerol in amniotic fluid. Am J Obstet Gynecol 145:474-480

19. Setaro F, Morley CG 1976 A modified fluorometric method for the determi- nation of microgram quantities of DNA from cell or tissue cultures. Anal Biochem 71:313-317

20. Hawgood S, Benson BJ, Hamilton Jr RJ 1985 Effect of a surfactant-associated protein and calcium ions on the structure and surface activity of lung surfactant lipids. Biochemistry 24:184-190

21. Laemmli UK 1970 Cleavage of structural proteins during the assembly of the head of bacteriophage T4. Nature 227:680-685

22. Fisher JH, Emrie PA, Shannon J, Sano K, Hattler B, Mason RJ 1988 Rat pulmonary surfactant protein $A$ is expressed as two differently sized mRNA species which arise from differential polyadenylation of one transcript. Biochim Biophys Acta 950:338-345

23. Yam J, Frank L, Roberts RJ 1978 Oxygen toxicity: comparison of lung biochemical responses in neonatal and adult rats. Pediatr Res 12:115-119

24. Kikkawa Y, Smith F 1983 Cellular and biochemical aspects of pulmonary surfactant in health and disease. Lab Invest 49:122-139

25. Young SL, Crapo JD, Kremers SA, Brumley GW 1982 Pulmonary surfactant lipid production in oxygen-exposed rat lungs. Lab Invest 46:570-576

26. Young SL, Wright JR, Clements JA 1989 Cellular uptake and processing of surfactant lipids and apoprotein SP-A by rat lung. J Appl Physiol 66:13361342

27. Nakamura H, Takada S, Sano K, Komura M, Matsuo T, Ohara H 1988 Impairment of superoxide release by alveolar macrophage in rats exposed to oxygen and vitamine E. Biol Neonate 54:29-34

28. Heffner JE, Repine JE 1989 Pulmonary strategies of antioxidant defense. Am Rev Respir Dis 140:531-554 